

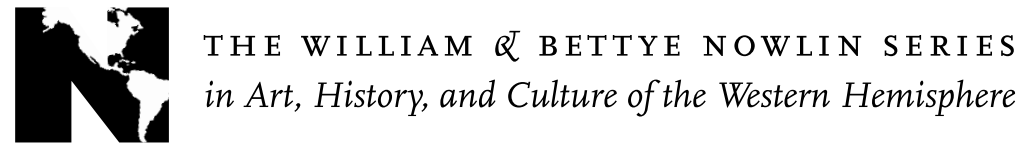




\title{
ADORING THE SAINTS
}

\author{
Fiestas in Central Mexico
}

YOLANDA LASTRA, DINA SHERZER, AND JOEL SHERZER

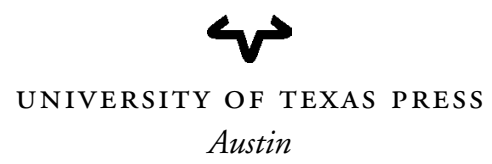


Copyright $\odot 2009$ by the University of Texas Press

All rights reserved

Printed in the United States of America

First edition, 2009

Requests for permission to reproduce material from

this work should be sent to:

Permissions

University of Texas Press

P.O. Box 7819

Austin, TX 78713-7819

www.utexas.edu/utpress/about/bpermission.html

(0) The paper used in this book meets the minimum requirements of ANSI/NISO Z39.48-I992 (RI997) (Permanence of Paper).

Library of Congress Cataloging-in-Publication Data

Lastra, Yolanda.

Adoring the saints : fiestas in central Mexico / Yolanda Lastra,

Dina Sherzer, and Joel Sherzer. - Ist ed.

p. cm. - (The William \& Bettye Nowlin series in art, history, and culture of the western hemisphere)

Includes bibliographical references and index.

ISBN 978-0-292-71980-4 (cloth : alk. paper)

I. Fasts and feasts-Mexico-San Luis de la Paz. 2. Fasts and feastsMexico-San Miguel de Allende. 3. Christian patron saints-MexicoSan Luis de la Paz. 4. Christian patron saints-Mexico-San Miguel de Allende. 5. Louis IX, King of France, I2I4-I270-Cult-Mexico-San Luis de la Paz. 6. Holy Week-Mexico-San Miguel de Allende.

7. Chichimeca-Jonaz Indians-Mexico-San Luis de la Paz-Religion.

8. Chichimeca-Jonaz Indians-Mexico-San Luis de la Paz-Social life and customs. 9. Otomi Indians-Mexico-San Miguel de AllendeReligion. Io. Otomi Indians-Mexico-San Miguel de Allende-Social life and customs. II. San Luis de la Paz (Mexico) - Religious life and customs. I2. San Miguel de Allende (Mexico) - Religious life and customs. I. Sherzer, Dina. II. Sherzer, Joel. III. Title.

BXI428.3.L37 2009

$263^{\prime} .9809724 \mathrm{I}-\mathrm{dc} 22$

2009006975 